\title{
Developing Barcorious Application as Teaching Media for English Young Students: Focus on Implication
}

\author{
Arimuliani Ahmad \\ Universitas Islam Riau, Pekanbaru, Indonesia \\ email: arimulianiahmad@edu.uir.ac.id
}

\begin{abstract}
Recently, teaching English for young learners especially for elementary school level still becomes problem in practice especially in Pekanbaru. Practically, the teachers teach their students without standard guidance to go with such as curriculum and syllabus because for fourth grades students, English Language subject looks like as extra subject which affects the effort to teach maximal. As response to this issue, the researcher has developed a learning media which focuses on vocabulary mastery which provides chance for the students to learn with or without teacher. There are five stages in developing this media which called by Barcorious such as analyzing students' need, designing media, developing content and design, implementation media, and evaluation. This study describes the implementation of Barcorious application to enhance students' vocabulary mastery. Indeed, this media was implemented for teaching four grade students. There was one class which consisted of 35 students participated. The finding shows this media can give significant improvement of students' vocabulary mastery because the students' post-test higher than pre-test.
\end{abstract}

Keywords: Barcorious Application, Vocabulary Mastery, English Young Students

\section{Pengembangan Aplikasi Barcorious sebagai Media Pembelajaran bagi Anak- Anak yang Mempelajari Bahasa Inggris: Fokus pada Implikasi}

\begin{abstract}
Abstrak
Baru-baru ini, mengajar bahasa Inggris untuk pelajar muda terutama untuk sekolah dasar masih menjadi masalah dalam praktik khususnya di Pekanbaru. Secara praktis, para guru mengajar siswa mereka tanpa panduan seperti kurikulum dan silabus yang berstandar nasional karena untuk empat siswa kelas, mata pelajaran Bahasa Inggris terlihat seperti subjek tambahan yang mempengaruhi upaya untuk mengajar maksimal. Sebagai tanggapan atas masalah ini, peneliti telah mengembangkan media pembelajaran yang berfokus pada penguasaan kosakata yang memberikan kesempatan bagi siswa untuk belajar dengan atau tanpa guru. Ada lima tahap dalam mengembangkan media ini yang disebut Barcorious, seperti menganalisis kebutuhan siswa, merancang media, mengembangkan konten dan desain, media implementasi, dan evaluasi. Penelitian ini mengujicobakan penerapan aplikasi Barcorious untuk meningkatkan penguasaan kosakata siswa. Media ini diimplementasikan untuk
\end{abstract}


mengajar siswa kelas empat sekolah dasar no 37 Pekanbaru. Sample dari penelitian ini adalah satu kelas yang terdiri dari 35 siswa. Temuan menunjukkan media ini dapat memberikan peningkatan yang signifikan terhadap penguasaan kosakata siswa yang dibuktikan dengan nilai post-test siswa yang lebih tinggi dari nilai pre-test siswa.

Keywords: Aplikasi Barcorious, Penguasaan Kosa Kata, Pebelajar Muda

\section{INTRODUCTION}

In Indonesia, English is one of the foreign languages that are learned by student at school. English language learning starts from Elementary School and students in this stage called as English Young Students (EYL). Santrock (2002) stated that the ages of 6 to 12 are late childhood age where the children have psychological characteristics, such as their desire to explore something new and curiosity. Therefore, basic education becomes the main concern. In attempting of giving a strong basic education by stimulating student's curiosity and providing optimum information of education for student, basic education is needed to be prepared carefully.

Based on the researcher's observation, English language teaching at Elementary School still use conventional teaching where the teacher uses classical lecture method. Teacher only uses book and seldom uses other teaching media. Book is considered as an unattractive media for student that makes ineffective learning.

The facts above contrast to the growth of technology these days. Children are interested in technology, such as smartphone. Smartphone is an interesting device for children because it has picture, animation, games and many other things. In fact, the teachers can use technological tools in teaching English to their students, especially in vocabulary mastery. The other aspect that needs to be concerned in teaching EYL is a joyful learning.

The conventional method and teaching media do not meet with the principles of effective learning and do not empower student's potentials. Teaching and learning activity should be able to optimize student's potentials to master expected competence. Teaching and learning process should be based on the principles, as follows: 1) studentcentered, 2) developing student's creativity, 3) creating joyful and challenging situation, 4) developing valuable ability, 5) providing variety of learning experience, 6) learning-bydoing.

Both teacher and student need an innovation of teaching media. Innovation of teaching media use to improve learning quality. One of the technological tools that can be used as an innovation of teaching media is computer. It supported by Surjono (1995:2) who stated that computer is one of technological tools that considered as teaching aids. However, all of computer features now can be accessed in a small size device that called as Smartphone.

Furthermore, there are several studies shown the impact of teaching and learning by utilizing online media gives 
positive impacts in teaching and learning (Wang et all: 2011; Saulnier: 2015 Mtebe: 2015; Seyal and Rahman: 2015; Ummunnakwe and Sello: 2016; KALELIOĞLU: 2017; MacKenzie et al: 2017; Ingalls: 2017; AL-NAIBI et all:2018). Next, Wang et all (2011) conducted their research by using Facebook Group as a Learning Management System (LSM). This research found that the students basically feel satisfied on using this media in learning. Then, Saulnier (2015) conducted his development research by using Flipped Classroom approach to integrate the course and technology in the classroom. The result shown that this media can increase students focus and participation in learning so that students' learning outcome improved. Besides, AL-NAIBI et all (2018) also conducted their research by using Edmodo. The result presented that the students' writing skill in paragraph can be improved significantly by using this media. In line of related studies which success in integrated technology in learning, the researcher assumes that in this millennium era, teachers should consider the importance of it and can design appropriate media by considering students' need, students' character and the language skill itself.

\section{Vocabulary}

Vocabulary is a basis of a language, it is very important to be mastered first. We cannot communicate with others even understand written materials without mastering vocabulary (Schmitt and McCharty: 1997; Ur: 1995). Hence, Piaget in Suyanto (2009:12) states that students of elementary school are a concrete thinker. They used to have a good learning when they are involved in an active learning. An active learning would make a more meaningful language acquisition if it related to real experiences in students' daily life. For instance, in teaching English vocabulary it would be good for teacher to choose a topic that close to them, such as things in the classroom. It would make them to have active and interested to learn English vocabulary.

According to Thornbury (2007:3), there are eight classes of vocabulary; they are pronouns, verbs, adjectives, adverbs, nouns, determiners, prepositions and conjunction. In addition, Glencoe (2000:24) divides vocabulary into eight types: verb, noun, pronoun, adjective, adverb, preposition, conjunction and interjection.

Based on those theories, the researcher concludes that vocabulary into following types.

1. Noun

A noun is a part of speech that denotes a person, animal, place, thing, or idea

2. Pronoun

A pronoun is the word that takes the place of a noun. In a sentence, it can be a subject or object and sometimes it can be possessive.

3. Adjective

An adjective is a describing word, the main syntactic role of which is to qualify a noun or noun phrase, giving more information about the object signified.

4. Verb

A word is used to describe an action, state, or occurrence, and forming the 
main part of the predicate of a sentence.

5. Adverb

An adverb is a word that modifies a verb, adjective, another adverb, determiner, noun phrase, clause, or sentence.

6. Preposition

A pronoun is a word or group of words that combines with a noun or pronoun to form a phrase that usually acts as an adverb, adjective, or noun.

7. Conjunction

A conjunction is a word used to connect clauses or sentences or to coordinate words in the same clause.

8. Interjection

An interjection is a word used to express a particular emotion or sentiment on the part of the speaker.

In addition, Kinberg (2007:23) states that one of the important aspects towards prior knowledge is vocabulary. It means that vocabulary plays important and dominant role in communication. In addition, Rivers in Nunan (1997:117) argues that the acquisition of an adequate vocabulary is essential for successful second language use. Moreover, Tarigan in Mardika (2008) states that vocabulary mastery represent one communication ability level, higher number of vocabulary that are mastered it makes a better quality of words delivered by someone.

2. Characteristics of EYL

Piaget in Suyanto (2009:12) states that students of elementary school are a concrete thinker. They used to have a good learning when they are involved in an active learning. An active learning would make a more meaningful language acquisition if it related to real experiences in students' daily life. For instance, in teaching English vocabulary it would be good for teacher to choose a topic that close to them, such as things in the classroom. It will make them to have active and interested to learn English vocabulary.

Budiningsih (2005:39) states that in preventing students' limitation of thinking. Teachers need to give a concrete representation to students so students able to analyze the issues. Students at the age of 7 to 12 years old still have a problem in abstract thinking. Generally, there are some characteristic of EYL. According to Suyanto (2009:16), there are 10 characteristics of EYL. The first character of EYL is egocentric where students at this ageused to have an interest to learn about something that related to their selves. They would be proud if teacher talk about something that related to them, such as their clothes color or their pet.

Second, EYL have a difficulty to distinguish a concrete and an abstract. They do not have an ability to analyze a real and unreal. Therefore, teachers should teach them from a concrete to an abstract.

Third, EYL also are active and imaginative learners. They like to have learning through pictures, fairytales and games (Ur, 1996). Learning in playing is an entertaining activity for EYL.

Fourth, EYL is easy bored. EYL have a low level of concentration. So, they used to become bored to do same thing for a long time. It is teachers' job to create variety activities in a short time, more and less 10 to 15 minutes.

Fifth, EYL's life is colorful. Therefore, activities and tasks with 
interesting and colorful pictures will make them happy. The use of colorful media will help teachers in delivering lessons to students because they will interest to the material. Then, an entertaining activity like learning through song, it used to make them quickly memorize a simple song, fun and easy to pronounce and it would be better if it is delivered with an appropriate movement.

Sixth, EYL like story as they like games. Through story, students are able to train their fully centered attention to a context rather than a word-by-word explanation. In a story activity, students are able to gather and receive an explicit message while games will make student becomes more active in learning.

Seventh, younger group prefer to do their task by their own but they also like to do their task together with their friends. They are fully self-centered untill age of 7 . Then, it slowly changed at the age of 7 to 8 because they got a change of social value. At this age, they also will like to share and work together with their friends.

Eighth, EYL at the age of 8 to 10 have enough awareness and readiness to language. They are able to understand a context of a conversation without a need to understand the meaning of each word because they are able to comprehend an intonation, facial expression and variety of movement.

Ninth, EYL like to use an intrinsic conversation to interact and talking about what they have. It is need by EYL in learning language. Teachers can take benefit from this EYL's characteristic to train them about interaction in English.
Tenth, EYL is an active thinker. They like to learn by doing something, such as playing and singing. They will enjoy a learning that involves their body movement to give a cue or a meaning of an expression. An oral learning is not enough for EYL, teacher also need to give examples, movement, expression, and the use of media like an object or picture to support them in language learning.

3. Teaching Media

Teaching media in the classroom are appropriate for triggering ideas, making difficult subjects more understandable, and for holding attention on important ideas. It should lead students to remember ideas by becoming more involved with them (Davis, 1991).

There several experts argue the benefits of using media of teaching. First, Sadiman (2002:17-18) states that some uses of teaching media are as follows: 1) clarifying a message, 2) solving the weaknesses of room, time and human senses, 3) a teaching media stimulates passive students to join class activity by using an appropriate teaching media, 4) giving a same stimulation and equalizing sudent's experience and perceptiontowards teaching material, 5) teaching media can give same experience to student about events in their environtment and also a possibility of a direct interaction with teachers, societies, and their environment through study tours, museum or zoo visit.

Then, Sudjana and Rifai in Sukiman (2012:43-44) states that some benefits of using teaching media in teaching and learning process, as follows: 1) Teaching media makes a more joyful learning for

Developing Barcorious Application as Teaching Media for English Young Students: Focus on Implication 
students that improves student's motivation, 2) Teaching media makes a clearer meaning of learning so students have better understanding and enable students to master and reach the goals of learning, 3) Teaching media makes variation of teaching method, 4) Students have a larger number activities in learning because they do not only listen to teacher's explanation.

To address those phenomena, the researcher intends to find out students' vocabulary mastery toward Barcorious application. In order to utilize this media in teaching, the researcher treat the students by integration it with a Picture Dictionary. It was designed from syllabus that is used as guidance in teaching English.

\section{Barcorious Application}

Barcorious Application is androidbased application. This application using the technology of barcode scanner that usually used on supermarket's cashier to scan the product details such as name, price, etc. But, in BAA the researcher was created this application using technology of barcode scanner to support English vocabulary teaching and learning.

The name of this applicationis derived from the 2 words "barcode" and "curious". Barcode is the main technology which the reseacher uses in this application and curios is one of the characteristic of English young students that are naturally curious and active. The reason why this word is chosen, this application is expected to take benefit of English young learners' characteristic of curious to improve their vocabulary through this application by finding a new Vocabulary in their environment.

It was created as a media to support teaching English vocabulary for English young learners. It can be categorized to audio and visual media because in applying this application in teaching and learning activity, it shows the vocabulary of a picture in English and the students can listen how to pronounce it through this application.

It is an Android application which it means an Android phone device is needed to operate this application. The minimum requirement of Android OS to operate this application is Android 4.0 (Ice Cream Sandwich).

Besides an Android phone, the other two additional Medias are required to operate this application. The first additional media is Picture Dictionary for Barcorious Application that contains some pictures with barcode. The pictures categorized per chapter. For example, fruits, animals, things in living room, etc.

Furthermore, this media has many advantages. It gives another variation in teaching vocabulary that involves technology of smartphone in teaching learning process. It gives some advantages for students in teaching English vocabulary, such as it stimulates students to learn new vocabulary by doing a thing. They grasp the meaning, imitate and practice pronunciation through observing what provided by it.

it also enhances students' motivation and enthusiasm in learning English vocabulary because it involves Smartphone in teaching vocabulary that has been associated with fun and games. English young students are so familiar 
with Smartphone and they love to use it. By using this media, it will increase their motivation in learning English vocabulary.

Since it improves students' attention, motivation and enthusiasm in teaching English vocabulary, it will make an enhancement of students' achievement. It increases their number of vocabularies as number of scanned pictures they do.

Beside the advantages of using it as teaching media for student, teachers can also take advantages from this application. Teachers have an alternative media for teaching English vocabulary and create a brand new class activity by using Smartphone for teaching learning activity.

\section{Picture Dictionary}

Picture Dictionary is used to support Barcorious Application. It is designed based on students' need for elementary level. It contains of ten topics such as animals, fruits, vegetables, nature, vehicles and transportations, things in the hospital, things in the classroom, things in the bedroom, things in the kitchen, and things in the living room. Every single picture has its barcode (coding) to be scanned to know the English word. It purposes to let students know the name of picture in English without translate it.

\section{METHOD}

This research was designed as quasi-experiment. It was assumed appropriate to conduct this research because it purposes to find out the significant effect of using Barcorious application toward students' vocabulary mastery. The population of this research was four grade students of SDN 37 Pekanbaru. To take the sample, the researcher used purposive sampling which selected $4 \mathrm{C}$ class.

Practically, the teacher used Barcorious application which was integrated with A Picture Dictionary in teaching vocabulary (see appendix 1). There were three topics were taught for four meeting such as Nature, Vehicles \& Transportations and Things in the Classroom.

Every meeting, the students learned vocabulary by using this application in group. Indeed, students use Barcorious media by using smartphone which are provided by the researcher. In learning, the students learn in group which consists of five students. There are several steps of using this media; 1) press "Barcorious" application in gadget menu, 2) press "start" button in home screen, 3) press "scan" button and point the camera at the picture in the picture dictionary, 4) place a barcode inside the viewfinder rectangle to scan it and then vocabulary will appear on the screen, 5) press "pronounce" button to know how to pronunciation of the word in English. 6) press "scan" button to continue scanning. To see the details open appendix 1 .

The researcher used vocabulary test to find out the students' vocabulary mastery in learning English. After conveying the data, the researcher analyzed the students' vocabulary mastery by comparing the students' 
score before and after treated by Barcorious Application. The result of data analysis was compared if $t_{\text {obserb }}$ and $t_{\text {table. If }} t_{\text {observe }}>t_{\text {table }}$ Ho is rejected. It means that there is significant effect of Barcorious Application toward students' vocabulary mastery. But if $t_{\text {observe }}<t_{\text {table, }}$ Ho is accepted. It means that there is significant effect of using Barcorious Application toward students' vocabulary mastery.

\section{FINDING AND DISCUSSION}

This section highlighted the impact of Barcorious application toward students' vocabulary mastery. The finding of the research showed in the following table 1 and figure 1 below;

\begin{tabular}{|c|c|c|}
\hline Siswa & Pre-test & $\begin{array}{c}\text { Post- } \\
\text { test }\end{array}$ \\
\hline Siswa 1 & 100 & 100 \\
\hline Siswa 2 & 100 & 90 \\
\hline Siswa 3 & 85 & 100 \\
\hline Siswa 4 & 55 & 60 \\
\hline Siswa 5 & 65 & 100 \\
\hline Siswa 6 & 25 & 80 \\
\hline Siswa 7 & 90 & 100 \\
\hline Siswa 8 & 45 & 90 \\
\hline Siswa 9 & 45 & 100 \\
\hline Siswa 10 & 80 & 90 \\
\hline Siswa 11 & 100 & 100 \\
\hline Siswa 12 & 100 & 100 \\
\hline Siswa 13 & 65 & 100 \\
\hline Siswa 14 & 90 & 100 \\
\hline Siswa 15 & 100 & 100 \\
\hline Siswa 16 & 100 & 100 \\
\hline Siswa 17 & 100 & 100 \\
\hline Siswa 18 & 50 & 100 \\
\hline
\end{tabular}

\begin{tabular}{|c|c|c|}
\hline Siswa 19 & 100 & 100 \\
\hline Siswa 20 & 75 & 100 \\
\hline Siswa 21 & 90 & 100 \\
\hline Siswa 22 & 70 & 90 \\
\hline Siswa 23 & 40 & 100 \\
\hline Siswa 24 & 90 & 100 \\
\hline Siswa 25 & 80 & 100 \\
\hline Siswa 26 & 40 & 80 \\
\hline Siswa 27 & 45 & 60 \\
\hline Siswa 28 & 100 & 100 \\
\hline Siswa 29 & 70 & 90 \\
\hline Siswa 30 & 35 & 100 \\
\hline Siswa 31 & 40 & 100 \\
\hline Siswa 32 & 65 & 100 \\
\hline Siswa 33 & 60 & 100 \\
\hline Siswa 34 & 85 & 100 \\
\hline Siswa 35 & 75 & 100 \\
\hline Rerata & & $\mathbf{9 5 . 1}$ \\
\hline
\end{tabular}

It can be seen that students' score are increased in posttest after using Barcorious android application. Barcorious has also impact number of students who have score $\geq 70$. It can be seen in the following table.

Table 2 Pre-test and Post-test Score

\begin{tabular}{|c|c|c|c|}
\hline No. & $\begin{array}{c}\text { Test } \\
\text { Type }\end{array}$ & $\begin{array}{c}\text { \% } \\
\geq 70 \\
\text { Score }\end{array}$ & Category \\
\hline 1 & Pretest & $57 \%$ & Very Poor \\
\hline 2 & Posttest & $91 \%$ & Excellent \\
\hline
\end{tabular}

Developing Barcorious Application as Teaching Media for English Young Students: Focus on Implication 


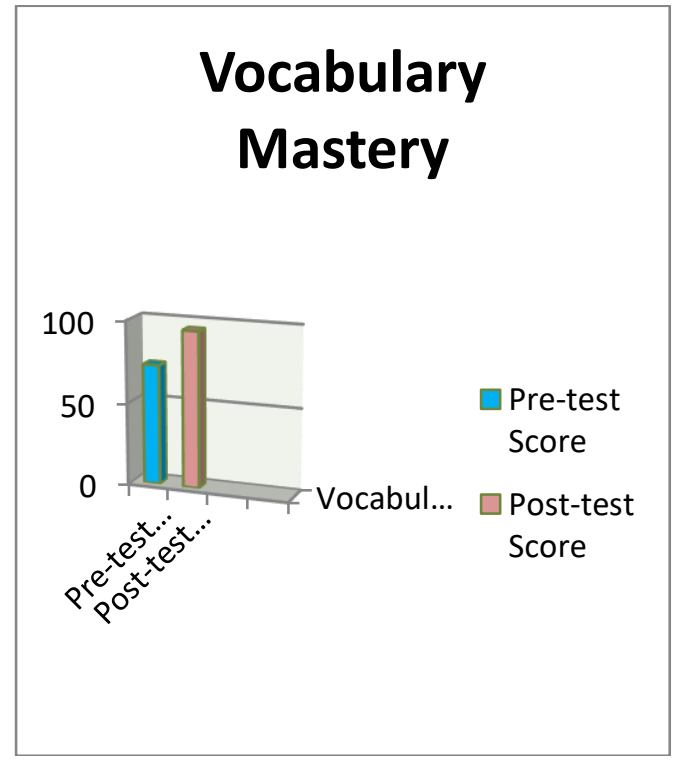

Figure 1. The Improvement of the Students' Vocabulary Mastery

Figure1 shows that the mean score of students' post-test is higher than pre-test. It proves that there is improvement on students' vocabulary mastery by using this media. Furthermore, statistical table below reveals the significant improvement of students' vocabulary mastery.

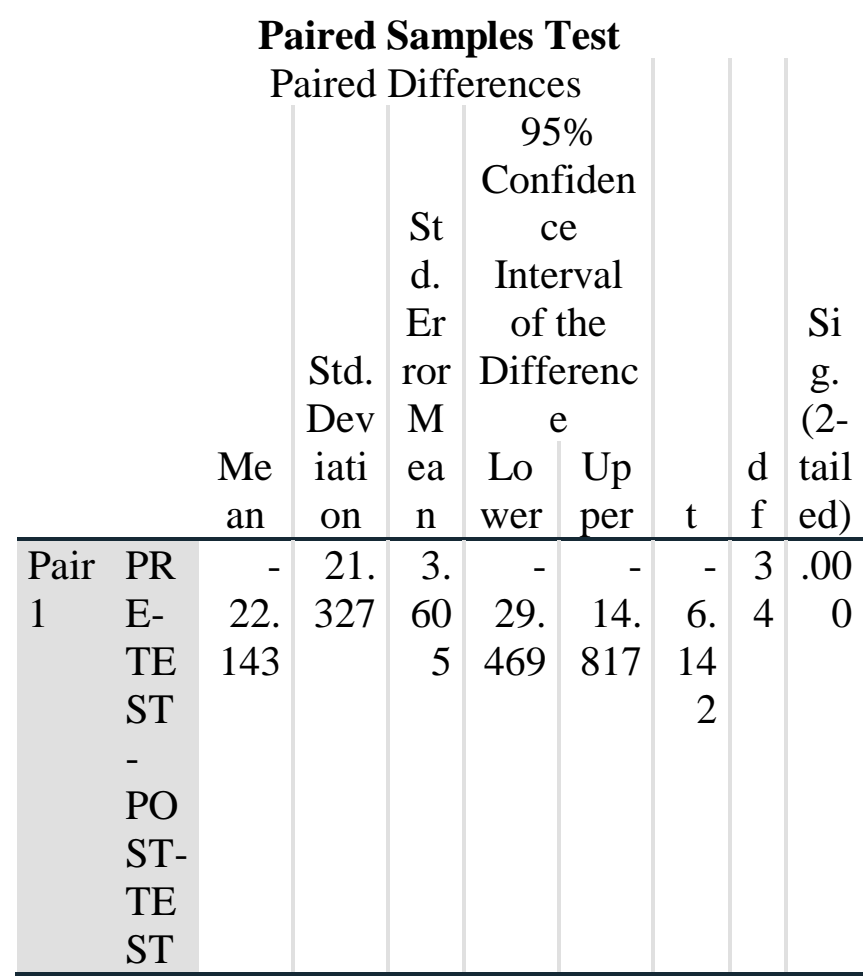

The statistical table above reveals that $t_{\text {table }} 0,017$ at the level of significant 0.05 and $t_{\text {observe was }} 0.061$. It is the same as tobserve $(0,061>$ $\mathrm{t}_{\text {table }}(0,017)$. It means that the null hypothesis was rejected. So, it can be concluded that there was significant improvement of students' vocabulary mastery by using Barcorious Application.

\section{CONCLUSION AND SUGGESTION}

Based on explanation above it can be concluded that in order to enhance young students' vocabulary mastery especially for four grade students of elementary school.

Furthermore, researcher hopes this research can give contribution for 
education field. First, for English lecturer, researcher recommends this kind of media to create an attractive teaching. A technology-based media is highly recommended to be involved in teaching because the students in present day are familiar with technological tools, such as smartphone, computer, etc. It will increase students in English learning if technological tools are involved. Second, researcher expected that this research will be a meaningful reference for those who are interested in conducting a research in the same areas of discussion.

\section{REFERENCES}

Al-NAIBI, Is'haq., AL-JABRI, Maryem., \& AL-KALBANI, Iman. (2018). Promoting Students' Paragraph Writing Using EDMODO: An Action Research. TOJET: The Turkish Online Journal of Educational Technology, January 2018, volume 17 issue 1.

Davis, B. H. 1991. Teaching with Media. Retrieved from http://www.mit.edu/ bhda vis/TeachMedia.html

Glencoe. 2000. Grammar and Composition Hand Book.New York: McGrau-Hill.

Ingalls, L. Amy. (2017). Facebook as a Learning-Management System in Developmental Writing. Journal of Developmental Education. Volume 40, Issue 2.
Mtebe, S., Joel. (2015). Learning Management System success: Increasing Learning Management System usage in higher education in sub-Saharan Africa. International Journal of Education and Development using Information and Communication Technology (IJEDICT), 2015, Vol. 11, Issue 2, pp. 51-64.

Sadiman, A.S. 2002. Media Pembelajaran dan Proses Belajar Mengajar, Pengertian Pengembangan dan Pemanfaatannya. Jakarta: Raja Grafindo Persada.

Santrock, J.W. 2002. Life-Span Development $\left(8^{\text {th }} \quad\right.$ edn.). New York: McGraw-Hill.

Saulnier, M, Bruce. (2015). The Flipped Classroom in Systems Analysis \& Design: Leveraging Technology to Increase Student Engagement. Information Systems Education Journal (ISEDJ). July, Vol 13 (4).

Schmitt, N. \& McCarthy, M. 1997. Vocabulary: Description, acquisition and pedagogy. Cambridge: Cambridge University Press.

Seyal, A. H., \& Rahman, N. A. (2007). The Influence Of External Variables On The Executives' Use Of The Internet. Business Process Management Journal,13(2), 263-278.

Suyanto, Kasihani K.E. 2009.English for Young Learners. Jakarta: Bumi Aksara. 
Surjono, H. 1995. Pengembangan Computer-Assisted Instruction (CAI) Untuk Pelajaran Elektronika. Jurnal Kependidikan. No. 2 (XXV): 95106.

Sukiman. 2012. Pengembangan Media Pembelajaran. Yogyakarta: Pedagogia.

Ur, Penny. 1998. A Course in Language Teaching: Practice and Theory. Cambridge: Cambridge University Press.

Umunnakwe, Ngozi \& Sello, Queen. Effective Utilization of ICT in English Language Learning - The Case of University of Botswana Undergraduates. Universal Journal of Educational Research 4(6): 1340-1350, 2016.

MacKenzie, Andrew., Muminovic, Milica., \& Oerlemans, Karin. (2017). The Intentional use of Learning Management Systems (LMS) to Improve Outcomes in Studio. JPBLHE: VOL. 5, NO. 1, 2017.

Wang, Qiyun., Woo, Lit, Huay., Quek, Lang, Choon., Yang, Yuqin and Liu, Mei. (2012). Using the Facebook group as a learning management system: An exploratory study. British Journal of Educational Technology. Vol 43 No 32012 428-438. 


\section{Appendix 1}

There are some steps in using this application. They are as below:
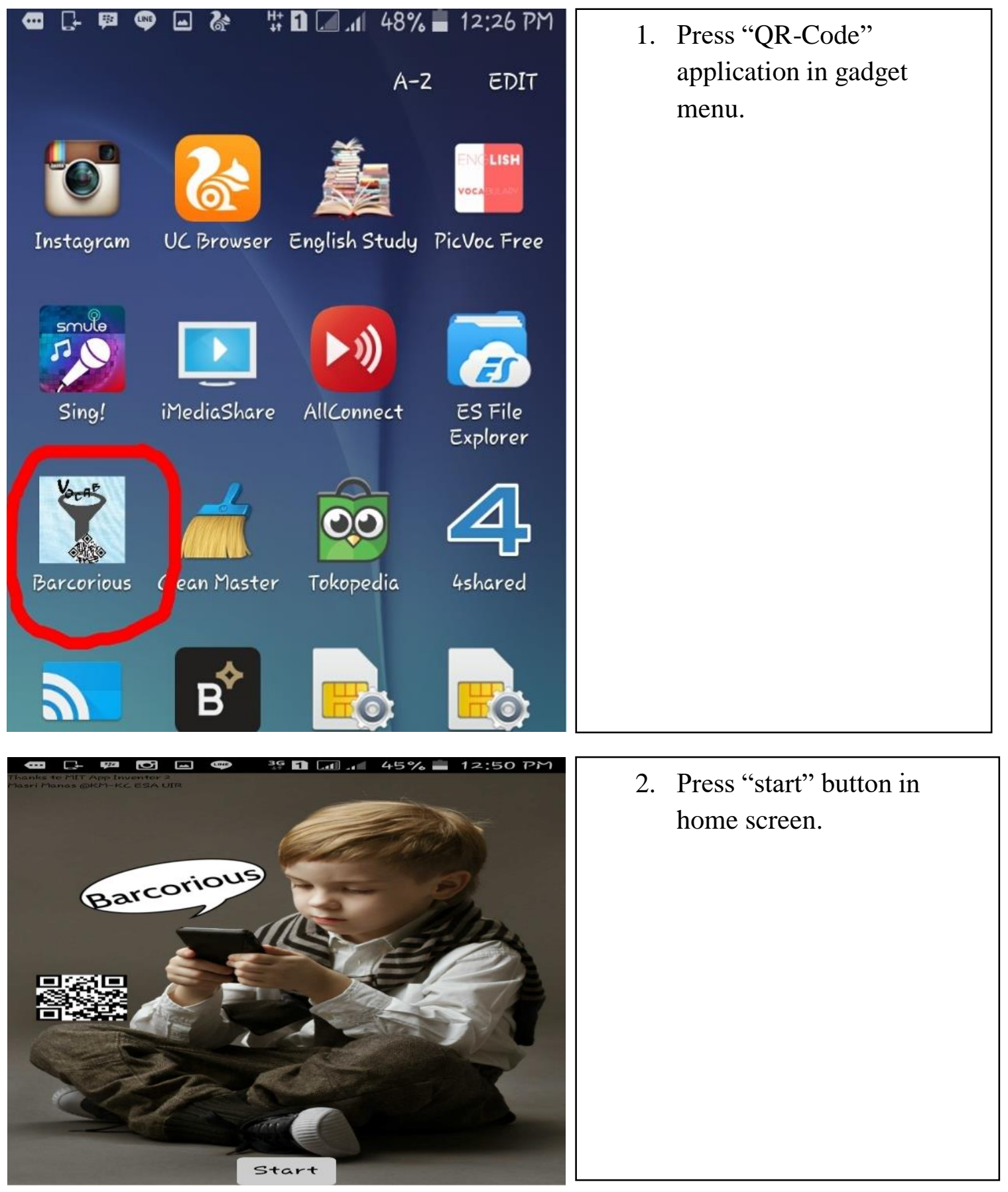


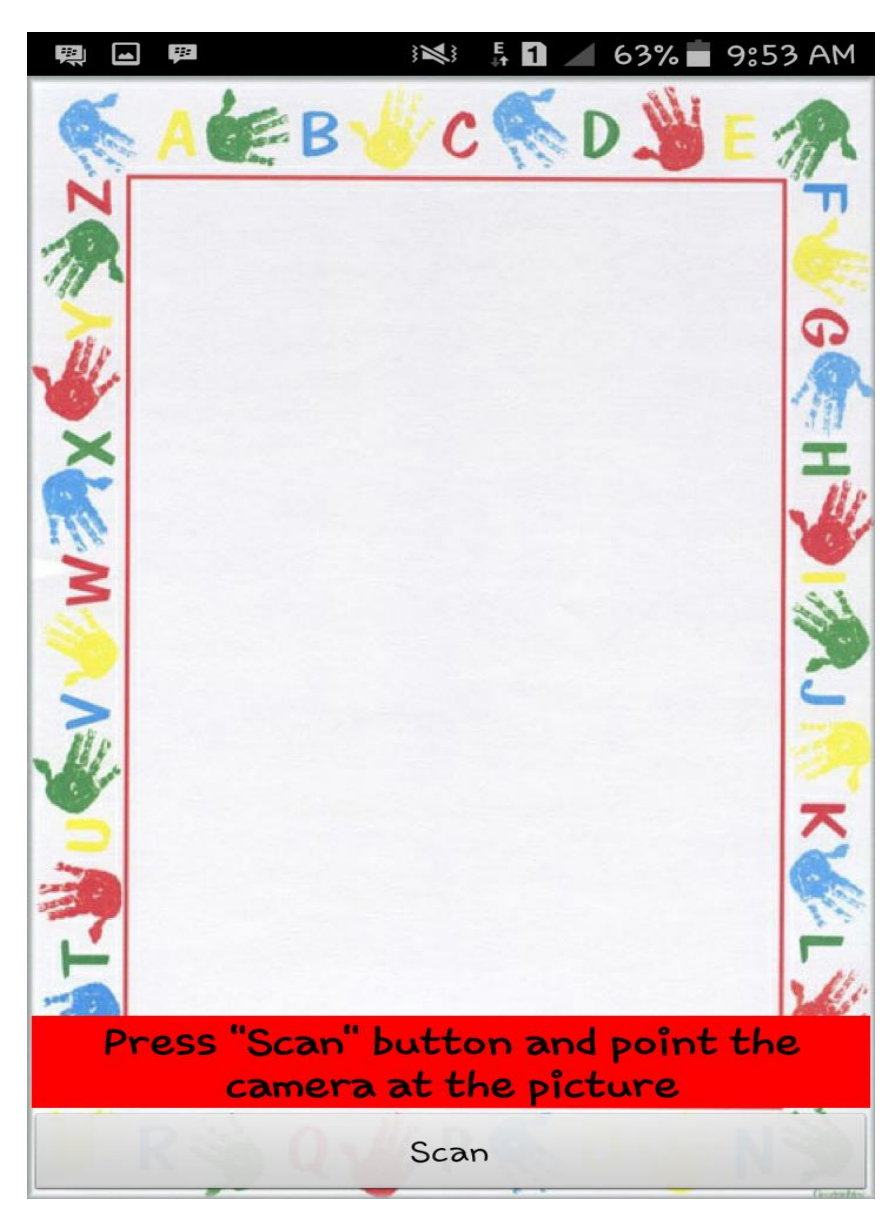
3. Press "scan" button and point the camera at the picture in picture dictionary.
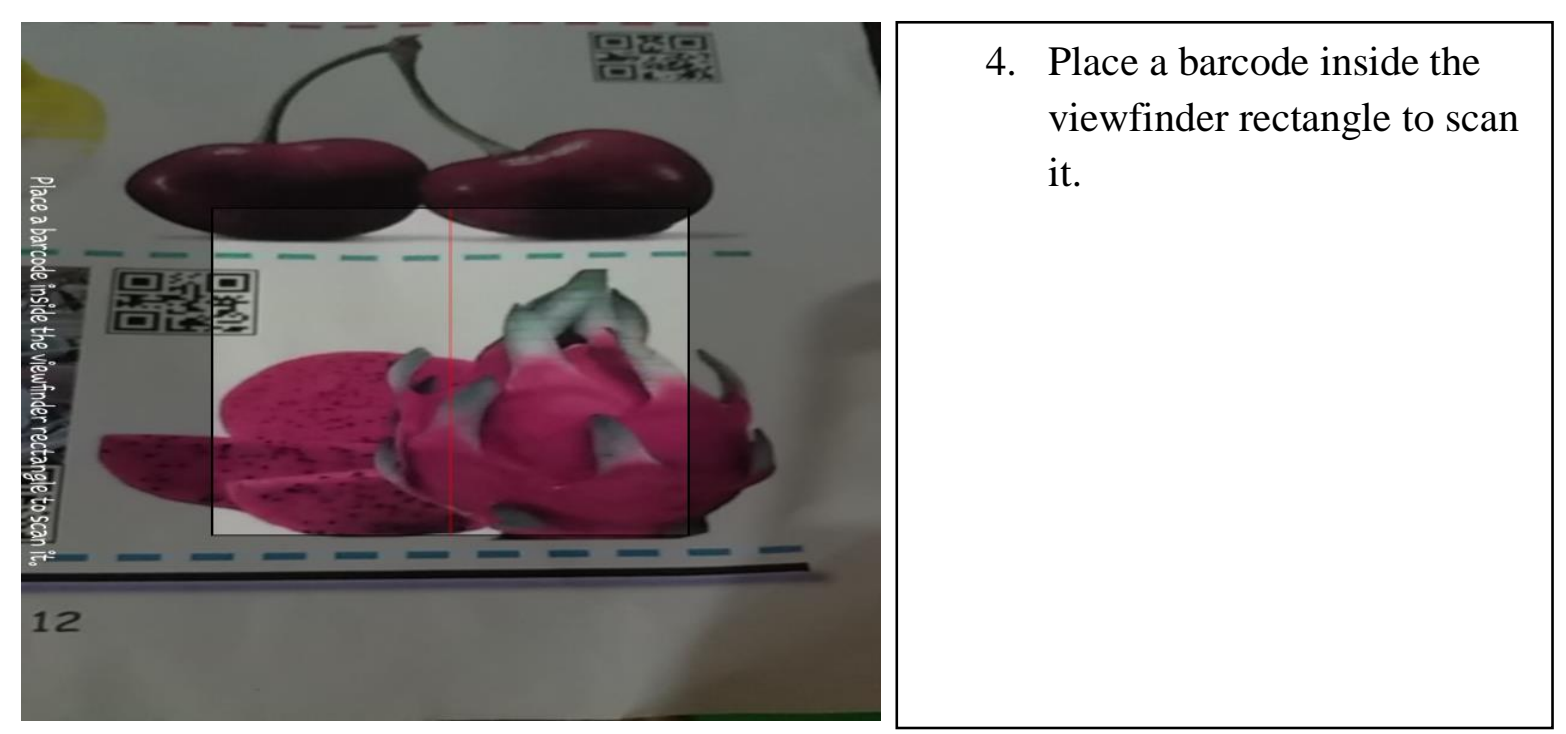


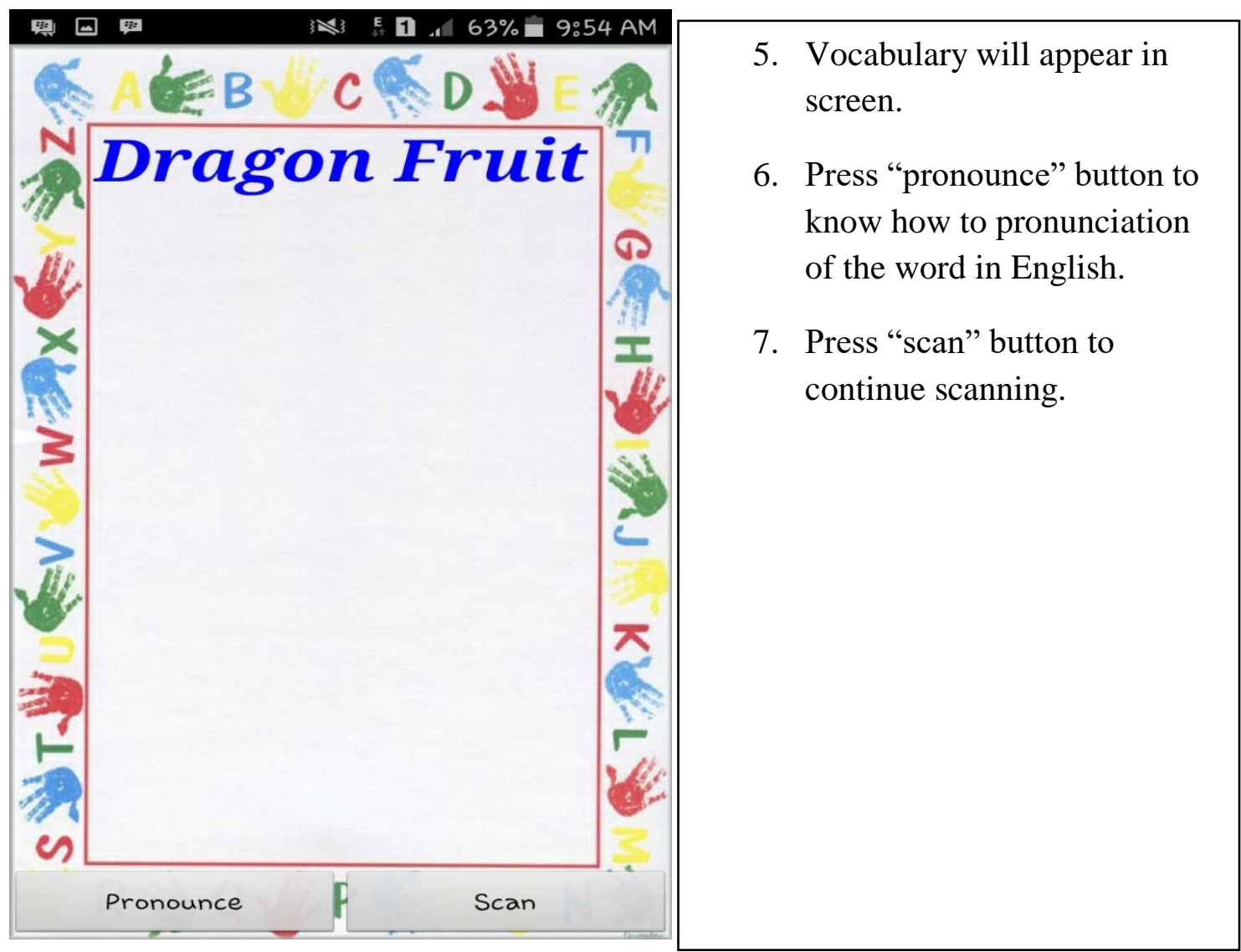

